\title{
Biosphere 2 project told to make room for science
}

\begin{abstract}
Washington. Biosphere 2, the $\$ 150$-million artificial ecosystem operating in the Arizona desert, may indeed be a grand experiment in living harmoniously with nature. But a new report from an outside panel says that the project will not generate any useful scientific results until it hires a scientific director, designs and carries out a research plan and makes its data available to outside scrutiny.
\end{abstract}

\section{IMAGE UNAVAILABLE FOR COPYRIGHT REASONS}

self-sustaining as it was made out to be supplies and air were being brought into the supposedly sealed environment and a carbon dioxide scrubber had been installed.

The success of the committee's suggestions, and the amount of money to be invested in basic research, depends largely on who is appointed as scientific director. Lovejoy estimates that the report's recommendations could be implemented for a few hundred thousand dollars. The company behind Biosphere 2, Space Biosphere Ventures, says that it was considering the appointment of a scientific director before the committee submitted its report.

The committee recommends that the director be a respected researcher with responsibility for coordinating the scientific activities of Biosphere 2, augmenting and facilitating new projects, developing the

Biosphere 2 - can it be more than a tourist attraction?

An eight-member committee of environmental scientists, chaired by ecologist Thomas Lovejoy of the Smithsonian Institution, was asked to describe what Biosphere 2 must do to make a meaningful contribution to science. The report does not say what type of research should be conducted nor how much it would cost, but Lovejoy praises the project as "an act of vision and courage" that will "make important scientific contributions in the fields of biogeochemical cycling, the ecology of closed systems and restoration ecology" if the panel's recommendations are carried out. The project has already produced results that would otherwise have been impossible to obtain, he says.

The story of Biosphere 2 is one of great hype followed by a certain amount of disillusionment. The idea was to set up a selfsustaining, artificial environment in which a number of people - or bionauts - would be sealed for two years. The aims were to generate scientific knowledge, to educate the public and to make a profit through tourism and new technology.

However, those involved in the early stages of the project say that science was low on the agenda in terms of both money and the interests of its organizers. The credibility of the project was further damaged when it was revealed that Biosphere 2, which began to operate last September, was not as

\section{Soviets reported to have dumped nuclear waste in Arctic}

Washington. Scientists from the United States and other countries are looking into reports that the Soviet Union dumped vast amounts of radioactive waste into the relatively shallow waters bordering the Arctic Ocean. The material is said to range from the intact reactor of a nuclear submarine to barrels of radioactive waste from nuclearpowered icebreakers.

Members of the Russian Parliament have asked their government to release data about the dumping, which is alleged to have occurred in the shallow Karas and Barents seas off the northwest coast of Russia between the 1960 s and last year. Last month, researchers and policy-makers from Canada, Russia and the United States met at the Woods Hole (Massachusetts) Oceanographic Institution (WHOI) to devise strategies for obtaining more data, including a conference next June in Canada to which Russian experts would be invited.

The researchers need to know the location, amount and packaging of the waste, as well as precisely what the Soviets dumped, before they can assess its possible effects. Officials from the former Soviet Union have released little information about the dumping, hampered by the decentralized and classified nature of the data.

"I can imagine that it's very difficult to find the information, because sometimes decisions were made by a few people", says Raphael Vartanov, a senior research fellow at WHOI's Marine Policy Center on leave from the Russian Academy of Sciences. Vartanov and others suspect that some bureaucrats are withholding data for fear of taking the blame or because they "still think in the old way".

Not content to wait for information, scientists have also organized expeditions to monitor known dump sites. A NorwegianRussian research team that also includes one US scientist is due to leave next week, and several US agencies are planning an international expedition in the autumn to take measurements at sea and on land.

Although few signs of extensive nuclear pollution have appeared in water leaving the Arctic, scientists are concerned that the effect of the alleged dumping could be magnified by the fact that it took place in seas only 60 to 300 metres deep. Such shallow waters harbour most of the ocean's organisms and are more turbulent than deeper ocean basins. Researchers also want to examine the water circulation around dump sites.

"I certainly don't think there is an ecological catastrophe happening", says Hugh Livingston, a senior research scientist at WHOI, "but I'm concerned for the future."

Traci Watson 